\title{
Nitrogen doses and splitting in top dressing in the production, quality, and macronutrients content in zucchini (Cucurbita pepo) seeds
}

\author{
Doses e parcelamento da adubação nitrogenada em cobertura na produção, qualidade e teor de \\ macronutrientes em sementes de abobrinha-de-moita (Cucurbita pepo) \\ Dosis y fraccionamiento de fertilización nitrogenada en cobertera sobre producción, calidad y \\ contenido de macronutrientes en semillas de calabacín (Cucurbita pepo)
}

Received: 07/25/2021 | Reviewed: 08/02/2021 | Accept: 08/07/2021 | Published: 08/13/2021

\author{
Ana Emília Barbosa Tavares \\ ORCID: https://orcid.org/0000-0003-0231-4735 \\ Centro Universitário Aparício Carvalho, Brazil \\ E-mail: anaemiliatavares@hotmail.com \\ Natália de Brito Lima Lanna \\ ORCID: https://orcid.org/0000-0001-6228-0392 \\ São Paulo State University, Brazil \\ E-mail: nataliabllanna@gmail.com \\ Lidiane Fernandes Colombari \\ ORCID: https://orcid.org/0000-0001-5788-6947 \\ São Paulo State University, Brazil \\ E-mail: colombarifl@yahoo.com.br \\ Emanuele Possas de Souza \\ ORCID: https://orcid.org/0000-0002-8039-2176 \\ São Paulo State University, Brazil \\ E-mail: emanuele.possas@unesp.br \\ Bruno Novaes Menezes Martins \\ ORCID: https://orcid.org/0000-0002-2664-6817 \\ University Center Southwest Paulista, Brazil \\ E-mail: brunonovaes17@hotmail.com \\ Antonio Ismael Inácio Cardoso \\ ORCID: https://orcid.org/0000-0003-3251-9491 \\ São Paulo State University, Brazil \\ E-mail: antonio-ismael.cardoso@unesp.br
}

\begin{abstract}
Despite the importance of the nutrients, mainly nitrogen, in the formation and chemical composition of the seeds, little research has been done to verify the relationship between the nutrients supplied to the plants and the quality of the seeds produced. The objective of this study was to evaluate the influence of nitrogen doses and splitting on yield, quality and macronutrients content in zucchini seeds. Two experiments (crop 2014 and crop 2015) were installed, with thirteen treatments in the factorial scheme $4 \times 3+1$, with four nitrogen doses in top dressing $(62.5 ; 125.0 ; 187.5 ; 250.0$ $\left.\mathrm{kg} \mathrm{ha}^{-1}\right)$, three splitting $(1 / 6+1 / 3+1 / 2 ; 1 / 4+1 / 2+1 / 4 ; 1 / 3+1 / 3+1 / 3$ of total dose in each split), and one treatment without $\mathrm{N}$ fertilization in top dressing (dose 0 ), with four replications. Seed production and quality and macronutrient content in seeds were evaluated. There wasn't significant effect on number of fruits and seeds produced per plant. However, in crop 2014 the higher the doses of $\mathrm{N}$ in top dressing, the higher the seed weight per fruit and per plant, the weight of 100 seeds and the vigor (first count in germination test). In crop 2015, seeds with the best quality (germination and first counting) were obtained in the $1 / 4+1 / 2+1 / 4$ splitting. The decreasing order of the macronutrient content in the seeds was $\mathrm{N}>\mathrm{P}>\mathrm{K}>\mathrm{Mg}>\mathrm{S}>\mathrm{Ca}$.
\end{abstract}

Keywords: Cucurbita pepo; Fertilizing; Germination; Nutrients; Vigor.

\section{Resumo}

Apesar da importância dos nutrientes, principalmente o nitrogênio, na formação e composição química das sementes, poucas pesquisas tem sido feitas para verificar a relação entre os nutrientes disponibilizados às plantas e a qualidade das sementes produzidas. O objetivo deste trabalho foi avaliar a influência de doses e parcelamento da adubação nitrogenada em cobertura na produtividade, qualidade e teor de macronutrientes em sementes de abobrinha. Foram instalados dois experimentos (safra 2014 e safra 2015), com treze tratamentos em esquema fatorial $4 \times 3+1$, com quatro doses de nitrogênio em cobertura $\left(62,5 ; 125,0 ; 187,5 ; 250,0 \mathrm{~kg} \mathrm{ha}^{-1}\right)$, três fracionamentos $(1 / 6+1 / 3+1 / 2 ; 1 / 4$ $+1 / 2+1 / 4 ; 1 / 3+1 / 3+1 / 3$ da dose total em cada divisão), e um tratamento sem fertilização de $\mathrm{N}$ em cobertura (dose 
0), com quatro repetições. Avaliaram-se a produção e a qualidade das sementes e o teor de macronutrientes nas sementes. Não houve efeito significativo no número de frutos e sementes produzidas por planta. Entretanto, na safra 2014, quanto maiores as doses de $\mathrm{N}$ em cobertura, maiores o peso da semente por fruto e por planta, o peso de 100 sementes e o vigor (primeira contagem no teste de germinação). Na safra 2015, as sementes com a melhor qualidade (germinação e primeira contagem) foram obtidas no parcelamento $1 / 4+1 / 2+1 / 4$. A ordem decrescente do teor de macronutrientes nas sementes de abobrinha-de-moita foi $\mathrm{N}>\mathrm{P}>\mathrm{K}>\mathrm{Mg}>\mathrm{S}>\mathrm{Ca}$.

Palavras-chave: Cucurbita pepo; Adubação; Germinação; Nutrientes. Vigor.

\section{Resumen}

A pesar de la importancia de los nutrientes, especialmente el nitrógeno, en la formación y composición química de las semillas, se han realizado pocas investigaciones para verificar la relación entre los nutrientes disponibles para las plantas y la calidad de las semillas producidas. El objetivo de este trabajo fue evaluar la influencia de las dosis y el fraccionamiento de la fertilización nitrogenada en cobertera sobre el rendimiento, la calidad y el contenido de macronutrientes en semillas de calabacín. Se instalaron dos experimentos (cultivo 2014 y cultivo 2015), con trece tratamientos en esquema factorial $4 \times 3+1$, con cuatro dosis de abono nitrogenado en cobertera $(62,5 ; 125,0 ; 187,5$; $\left.250,0 \mathrm{~kg} \mathrm{ha}^{-1}\right)$, tres fraccionamientos $(1 / 6+1 / 3+1 / 2 ; 1 / 4+1 / 2+1 / 4 ; 1 / 3+1 / 3+1 / 3$ de la dosis total en cada división), y un tratamiento sin fertilización con $\mathrm{N}$ en cobertera (dosis 0 ), con cuatro repeticiones. Se evaluó la producción y calidad de la semilla y el contenido de macronutrientes en las semillas. No hubo un efecto significativo sobre el número de frutos y semillas producidos por planta. Sin embargo, en cultivo 2014, a mayor dosis de N en cobertera, mayor peso de semilla por fruto y por planta, peso de 100 semillas y vigor (primer recuento en la prueba de germinación). En cultivo 2015, las semillas con mejor calidad (germinación y primer conteo) se obtuvieron en el fraccionamiento $1 / 4+1 / 2+1 / 4$. El orden descendente del contenido de macronutrientes en las semillas fue $N>P>K>$ $\mathrm{Mg}>\mathrm{S}>\mathrm{Ca}$.

Palabras clave: Cucurbita pepo; Fertilizante; Germinación; Nutrientes; Vigor.

\section{Introduction}

A balanced fertilization is essential in the production of seeds, due to the fact that the nutrients participate in the seed formation, development and maturation phases, being part of the membrane constitution and in the accumulation of lipids, carbohydrates and proteins, reflecting in the size, weight and chemical composition of seeds (Carvalho \& Nakagawa 2012).

However, despite the importance of the nutrients in the formation and chemical composition of the seeds, little research has been done to verify the relationship between the nutrients supplied to the plants and the quality of the seeds produced (Cardoso 2011; Magro et al. 2010).

In zucchini, there are fertilization recommendations for the production of commercial immature fruits (Araújo et al. 2013 ; 2015). However, when the focus of the crop is the production of seeds, this fertilization may be insufficient, as the plants stay for longer time in the field and the seeds, still in the beginning of formation in the immature fruit, are the main drains in the ripe fruit (Cardoso 2011).

In the reproductive phase, the nutritional requirement of the plants is more intense and nutrients are intensely translocated to seed formation. Among these nutrients, nitrogen is prominent in seed formation, as it is involved in the constitution of proteins, starch synthesis, embryo formation and reserve tissue. Nitrogen can also influence the physiological quality of the seeds, but their effects vary with the environmental conditions and the stage of development of the plant in which the fertilizer application occurs (Carvalho \& Nakagawa 2012).

Nitrogen is the second most extracted nutrient by immature fruits in zucchini (Araújo et al. 2015), with part being supplied in planting fertilization, and the rest distributed in three equal applications in top dressing fertilization (Trani \& Raiji 1997), because it is a nutrient easily lost by volatilization and leaching and the plants require different amounts during the developmental stages (Cardoso 2011; Corrêa et al. 2014; Cardoso et al 2016). But there are few researches about top dressing fertilization in vegetable seed production and quality.

The objective of this study was to evaluate the influence of nitrogen doses and splitting on yield, quality and macronutrients content in zucchini seeds. 


\section{Methodology}

Two experiments were carried out, one in 2014 (Crop 2014) and another in 2015 (Crop 2015), both in the São Manuel Experimental Farm, located in the municipality of São Manuel, Brazil, belonging to the School of Agriculture (FCA) of the Sao Paulo State University (UNESP). The geographical coordinates are: $22^{\circ} 46$ 'South latitude, $48^{\circ} 34^{\prime}$ West longitude and 740m altitude. The climate of the São Manuel region is Cfa, warm temperate (mesothermal) and humid (Cunha \& Martins 2009) and the soil is a Typical Red Dystrophic Latosol. It is a sandy soil with $84 \%$ sand.

The results obtained in the soil chemical analysis were: Crop 2014: $\mathrm{pH}\left(\mathrm{CaCl}_{2}\right)=5.8$; organic matter $=12 \mathrm{~g} \mathrm{dm}^{-3} ; \mathrm{H}_{+}$

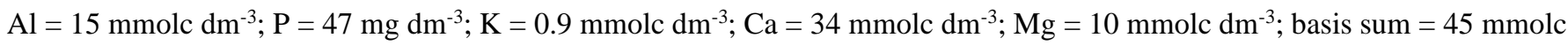

$\mathrm{dm}^{-3} ; \mathrm{CEC}=60$ mmolc dm ${ }^{-3} ;$ saturation basis $(\mathrm{V})=75 \% ; \operatorname{crop} 2015: \mathrm{pH}\left(\mathrm{CaCl}_{2}\right)=5.1 ;$ organic matter $=11 \mathrm{~g} \mathrm{dm}{ }^{-3} ; \mathrm{H}+\mathrm{Al}=29$ mmolc dm ${ }^{-3} ; \mathrm{P}=186 \mathrm{mg} \mathrm{dm}^{-3} ; \mathrm{K}=1.9 \mathrm{mmolc} \mathrm{dm}^{-3} ; \mathrm{Ca}=18 \mathrm{mmolc} \mathrm{dm}^{-3} ; \mathrm{Mg}=3 \mathrm{mmolc} \mathrm{dm}^{-3} ;$ basis sum $=24 \mathrm{mmolc} \mathrm{dm}^{-3}$; $\mathrm{CEC}=53$ mmolc $\mathrm{dm}^{-3}$; saturation basis $(\mathrm{V})=45 \%$.

Based on the soil chemical analysis, liming was done on area of crop 2015 and fertilization, in both crops, was carried out according to the recommendation of Trani \& Raij (1997): $40 \mathrm{~kg} \mathrm{ha}^{-1}$ of N, $200 \mathrm{~kg} \mathrm{ha}^{-1}$ of $\mathrm{P}_{2} \mathrm{O}_{5}, 100 \mathrm{~kg} \mathrm{ha}^{-1}$ of K2 $\mathrm{O}$ and $30 \mathrm{t}$ $\mathrm{ha}^{-1}$ (humid base) of organic compost $\left(\mathrm{N}=0.6, \mathrm{P}_{2} \mathrm{O}_{5}=1.0, \mathrm{~K}_{2} \mathrm{O}=3.0, \mathrm{Ca}=2.3, \mathrm{Mg}=0.2, \mathrm{~S}=0.3, \mathrm{U}\left(65^{\circ} \mathrm{C}\right)=28\right.$, organic matter $=21,0, \mathrm{C}=12.0$, expressed as $\%$ dry matter). After the incorporation of the fertilizers, the soil was prepared in beds, with a height of $0.20 \mathrm{~m}$ and a width of $1.40 \mathrm{~m}$.

Thirteen treatments, in the $4 \times 3+1$ factorial scheme, were studied, with four replications in a randomized complete block design, in both experiments. The factors were four doses of nitrogen in top dressing $(62.5,125.0,187.5 \mathrm{and} 250.0 \mathrm{~kg} \mathrm{ha}$ 1 of $\mathrm{N})$, three fertilization splitting $(1 / 6+1 / 3+1 / 2 ; 1 / 4+1 / 2+1 / 4 ; 1 / 3+1 / 3+1 / 3$ of total dose in each split), in addition to the control (without nitrogen fertilization in top dressing, considered dose $0 \mathrm{~kg} \mathrm{ha}^{-1}$ ).

Total doses were divided in three applications at 21 (vegetative development), 35 (beginning of flowering) and 49 (fruit and seed maturation) days after transplant (DAT). Urea $(45 \% \mathrm{~N})$ was used as the nitrogen source. For the definition of $\mathrm{N}$ doses, the mean dose $\left(125 \mathrm{~kg} \mathrm{ha}^{-1}\right)$ recommended by Trani and Raij (1997) for nitrogen fertilization in top dressing in zucchini fruit production was used as reference. Concomitant to $\mathrm{N}$ in top dressing, $90 \mathrm{~kg} \mathrm{ha}^{-1}$ of $\mathrm{K}_{2} \mathrm{O}$ in the form of potassium chloride $\left(60 \% \mathrm{~K}_{2} \mathrm{O}\right)$ was applied in all experimental plots, including the control (without $\mathrm{N}$ in top dressing), in the same ratio: $1 / 3+1 / 3+1 / 3$.

The cultivar Caserta was used, with sowing done on 08/18/2014 (crop 2014) and on 07/29/2015 (crop 2015). Transplantation was performed 14 days after sowing (DAS), in both experiments, with $0.7 \mathrm{~m}$ between rows and $1.0 \mathrm{~m}$ between plants, totaling 15 plants per plot (three lines of five plants), and the three central plants were considered the useful plot.

Harvests of ripe fruits started at 60 and 66 DAT and ended at 82 and 78 DAT, in experiments 1 (crop 2014) and 2 (crop 2015), respectively, followed by fruits post harvest rest for approximately 15 days for complete maturation of the seeds inside the fruits (Cardoso \& Souza Neto 2016), before seed extraction (20\% of average water content). After the extraction, the seeds were stored in a dry chamber $\left(20^{\circ} \mathrm{C}\right.$ and $\left.40 \% \mathrm{RH}\right)$ for about 30 days, when the water content stabilized in $9 \%$. After this period, the seeds were benefited in seed separator by density. After this process, the seeds of each plot were weighed (accuracy of $0.0001 \mathrm{~g})$.

In both crops, the following characteristics were evaluated: number of ripe fruits per plant, average fruit weight, length of the fruit, seed production (number and weight) per fruit and per plant, germination and vigor of seeds.

For the germination and vigor test (first count), the seeds were placed on two sheets of pre-moistened towel paper, covered by another sheet, and placed vertically in a germination chamber type BOD at a temperature of $25^{\circ} \mathrm{C}(\mathrm{Brasil} 2009)$, with four replicates of 50 seeds. First count (only radicle protrusion) was evaluated at the $4^{\text {th }}$ days after sowing (DAS), and total germination (normal seedlings) was performed at $8^{\text {th }}$ DAS, both expressed in $\%$. 
The determination of the macronutrients (N, P, K, Ca, Mg, S) content in seeds was performed only in crop 2015 . For this, on the day of the seed extraction, a seed sample per plot was packed in a paper bag and placed in a forced air circulation oven at $65{ }^{\circ} \mathrm{C}$ until reaching a constant weight $( \pm 48$ hours). After drying, the samples were analyzed according to methodology presented by Malavolta et al. (1997), and results were expressed in $\mathrm{g} \mathrm{kg}^{-1}$ of dry weight (DW).

Data were submitted to variance and regression analysis to verify the effect of nitrogen doses, defining the best fit according to combination of significance and higher coefficient of determination, and Tukey's test ( $p>0.05)$ for determination of the effect of splitting. The data were processed by the Sisvar 5.3 computer statistical analysis system (Ferreira 2011).

\section{Results}

To crop 2014, the treatments did not influence the number of fruits (1.5 fruits per plant), average fruit weight (1.1 kg) and fruit length $(31.7 \mathrm{~cm})$, also did not influence some characteristics related to the seed production as the number of seeds per fruit (273 seeds) and number of seeds per plant (379 seeds).

For the characteristics seed weight per fruit, first count and final germination, there was interaction between the nitrogen doses and splitting, and for weight of 100 seeds and seed weight per plant there was an effect only for doses of N. For the 100 seed weight, the effect of the doses was linear, with an estimated mean increase of $30.1 \%$ in the dose $250 \mathrm{~kg} \mathrm{ha}^{-1}$ of $\mathrm{N}$ compared to the control (dose 0 ) (Figure 1).

Figure 1. Weight of 100 seeds as a function of the nitrogen doses in top dressing. Crop 2014.

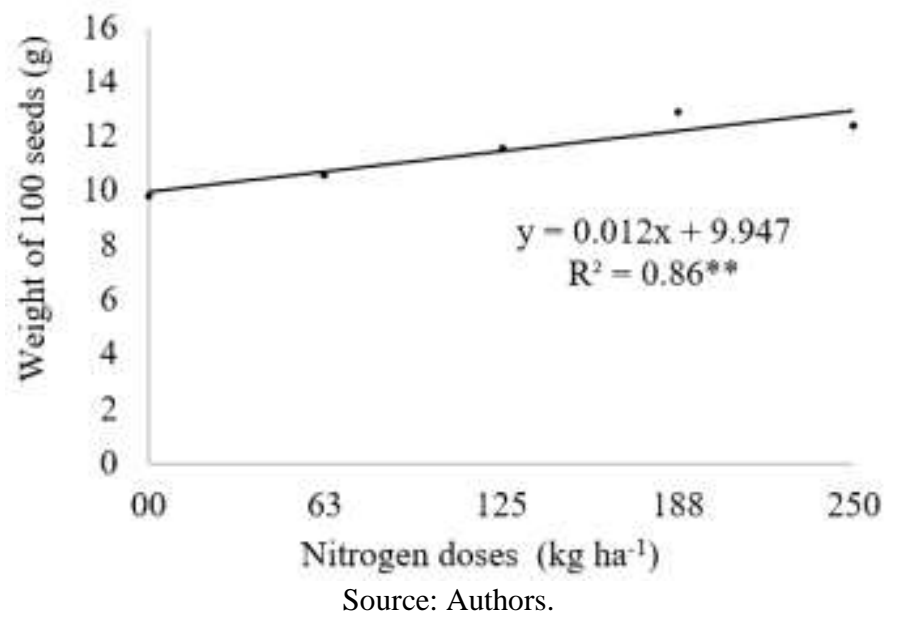

Despite there is no difference in seed number per fruit, as the 100 seed weight increased with doses of $\mathrm{N}$, it was observed a linear effect for weight of seeds per fruit, in all the splitting, with an increase of $36.7 \%, 26.9 \%$ and $28.2 \%$ in the seed production $(\mathrm{g})$ per fruit in the dose $250 \mathrm{~kg} \mathrm{ha}^{-1}$ of $\mathrm{N}$ compared to the control (dose 0 ) in the $1 / 6+1 / 3+1 / 2,1 / 4+1 / 2+1 / 4$ and $1 / 3+1 / 3+1 / 3$ splitting, respectively (Figure $2 \mathrm{~A}$ ). For seed production (g) per plant, the means were adjusted to the linear model, without interactions, with an increase of approximately $34.7 \%$ in the seed weight at the dose $250 \mathrm{~kg} \mathrm{ha}^{-1}$ of $\mathrm{N}$ when compared to the control, regardless the splitting (Figure 2B). 
Figure 2. Seed weight per fruit (A) and per plant (B) as a function of the nitrogen doses applied in top dressing in each splitting. Crop 2014.
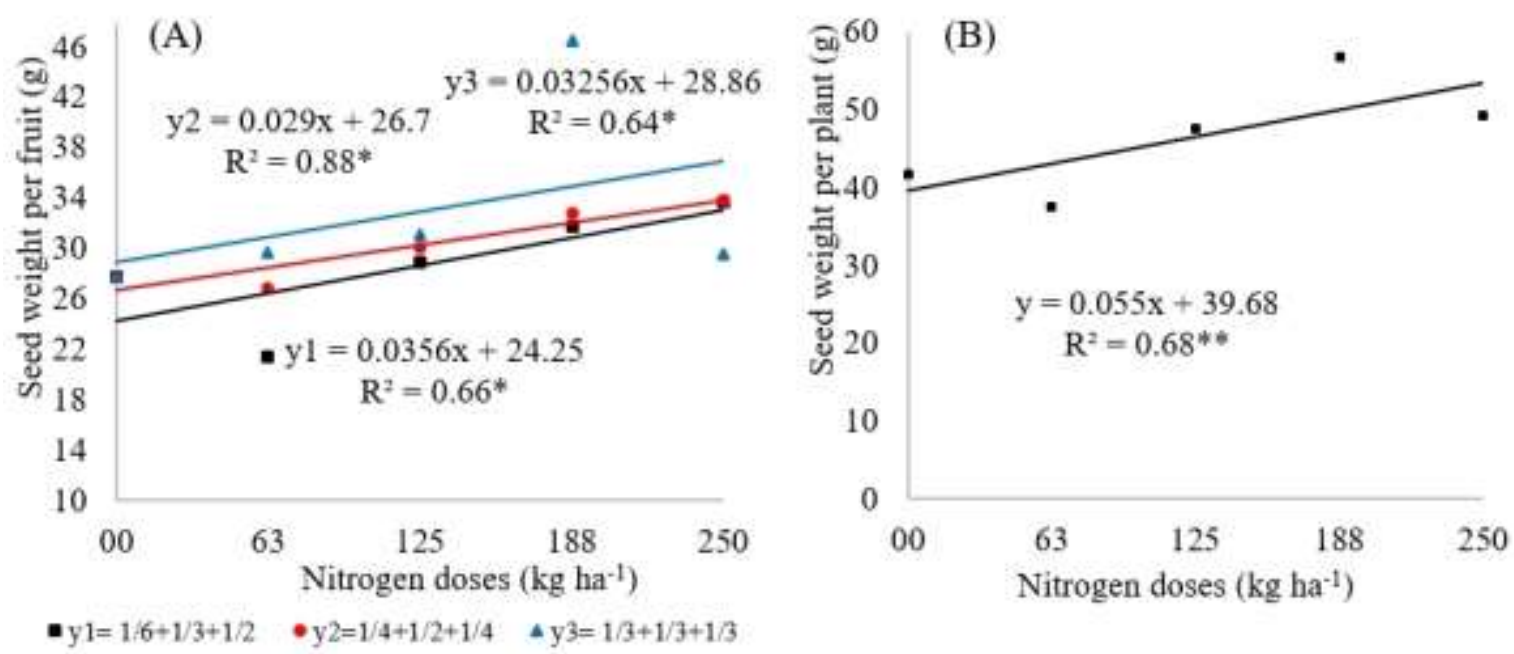

Source: Authors.

The averages of the first seed germination count in the $1 / 6+1 / 3+1 / 2$ and $1 / 4+1 / 2+1 / 4$ splitting increased the higher the doses of $\mathrm{N}$, with a maximum of $90.2 \%$ and $87.9 \%$ in the highest dose, respectively. In the $1 / 3+1 / 3+1 / 3$ split, there were not effect for nitrogen fertilization, with a mean of $78.7 \%$ at the first count (Figure 3A). The seed germination averages in the $1 / 6+1 / 3+1 / 2$ splitting had a linear increase ranging from $70.8 \%$ (control) to $87.5 \%$ (highest dose). In the $1 / 4+1 / 2+1 / 4$ and $1 / 3+1 / 3+1 / 3$ splitting, the quadratic effect was obtained, with an increase in germination percentage with a maximum estimated in $87.3 \%$ at dose $163 \mathrm{~kg} \mathrm{ha}^{-1}$ of $\mathrm{N}$ and $83.4 \%$ in the dose $115 \mathrm{~kg} \mathrm{ha}^{-1}$ of $\mathrm{N}$, respectively (Figure $3 \mathrm{~B}$ ).

Figure 3. First germination count (A) and final germination (B) of zucchini seeds as a function of the nitrogen doses applied in top dressing in each splitting. Crop 2014.
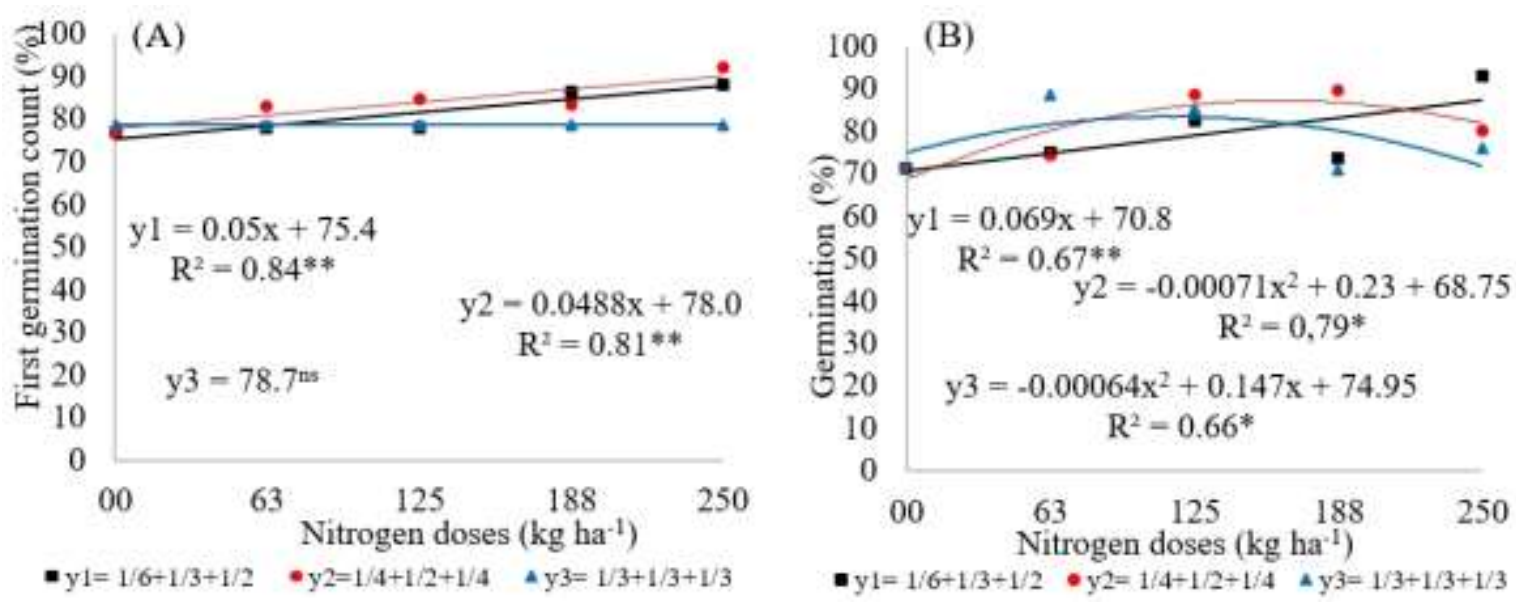

Source: Authors.

To crop 2015, no statistical differences were observed for the number of fruits per plant (1.3 fruits), fruit weight $(1,275 \mathrm{~g}$ per fruit), length $(33.4 \mathrm{~cm})$, number of seeds per fruit (233.5), weight of 100 seeds $(9.35$ grams), seed weight per fruit $(21.0 \mathrm{~g})$ and seed weight per plant $(27.3 \mathrm{~g})$.

For the first count and the total germination there was difference for splitting, doses and interaction between factors. The 1/4+1/2+1/4 splitting was superior to the other splits in the two lowest doses for the first count and also in the higher dose 
for the total germination (Table 1).

Table 1. First count and final germination of zucchini seeds as a function of the nitrogen doses applied in top dressing in each splitting. Crop 2015.

First count $(\%) \quad$ Germination $(\%)$

\begin{tabular}{|c|c|c|c|c|c|c|c|c|}
\hline \multirow[t]{2}{*}{ Splitting } & \multicolumn{4}{|c|}{ Nitrogen doses $\left(\mathrm{kg} \mathrm{ha}^{-1}\right)$} & \multicolumn{4}{|c|}{ Nitrogen doses $\left(\mathrm{kg} \mathrm{ha}^{-1}\right)$} \\
\hline & $62,5^{* *}$ & $125,0 * *$ & $187,5^{* *}$ & $250,0^{* *}$ & $62,5 * *$ & $125,0 * *$ & 187,5 & $250,0 * *$ \\
\hline $1 / 6+1 / 3+1 / 2$ & $64,5 b$ & $62,3 b$ & $76,3 \mathrm{a}$ & $74,3 b$ & $67,0 \mathrm{~b}$ & $61,8 b$ & $72,8 \mathrm{a}$ & $70,8 b$ \\
\hline $1 / 4+1 / 2+1 / 4$ & $99,0 \mathrm{a}$ & $88,8 \mathrm{a}$ & $64,0 \mathrm{~b}$ & $91,8 \mathrm{a}$ & $94,0 \mathrm{a}$ & $89,8 \mathrm{a}$ & $58,5 \mathrm{a}$ & $90,8 \mathrm{a}$ \\
\hline $1 / 3+1 / 3+1 / 3$ & $74,5 b$ & $62,0 b$ & $55,0 \mathrm{~b}$ & $84,8 \mathrm{ab}$ & $77,5 b$ & $65,0 b$ & $63,0 \mathrm{a}$ & $75,3 b$ \\
\hline
\end{tabular}

** Means followed by same letter in colunms do not differ each other by Tukey test $(\mathrm{p}<0,05)$. Source: Authors.

For doses of N, the first germination count showed different behavior for each splitting. In the $1 / 6+1 / 3+1 / 2$ splitting, the mean of the first germination count responded linearly to the dose increasing, ranging from $60.6 \%$ (dose 0 ) to $75.1 \%$ at the highest dose $\left(250 \mathrm{~kg} \mathrm{ha}^{-1}\right.$ of $\left.\mathrm{N}\right)$. In the $1 / 4+1 / 2+1 / 4$ and $1 / 3+1 / 3+1 / 3$ splitting, a quadratic effect was obtained, with a maximum estimated germination of $86.5 \%$ in the dose of $158 \mathrm{~kg} \mathrm{ha}^{-1}$ of $\mathrm{N}$ for the $1 / 4+1 / 2+1 / 4$ and $68.2 \%$ in the highest dose (250 $\mathrm{kg} \mathrm{ha}^{-1}$ of $\mathrm{N}$ ) in the $1 / 3+1 / 3+1 / 3$ splitting (Figure $\left.4 \mathrm{~A}\right)$.

The total germination averages in the $1 / 6+1 / 3+1 / 2$ splitting did not respond to the increase of $\mathrm{N}$ doses, with an average of $67.5 \%$. In the $1 / 4+1 / 2+1 / 4$ splitting, the germination averages responded with a cubic effect, with maximum germination estimated in $100 \%$ at the dose $185 \mathrm{~kg} \mathrm{ha}^{-1}$ of $\mathrm{N}$. Behavior similar was observed in the $1 / 3+1 / 3+1 / 3$ splitting with maximum germination estimated in $100 \%$ at the dose $106 \mathrm{~kg} \mathrm{ha}^{-1}$ of $\mathrm{N}$ (Figure $4 \mathrm{~B}$ ).

Figure 4. First germination count (A) and total germination (B) of zucchini seeds as a function of the nitrogen doses applied in top dressing in each splitting. Crop 2015.
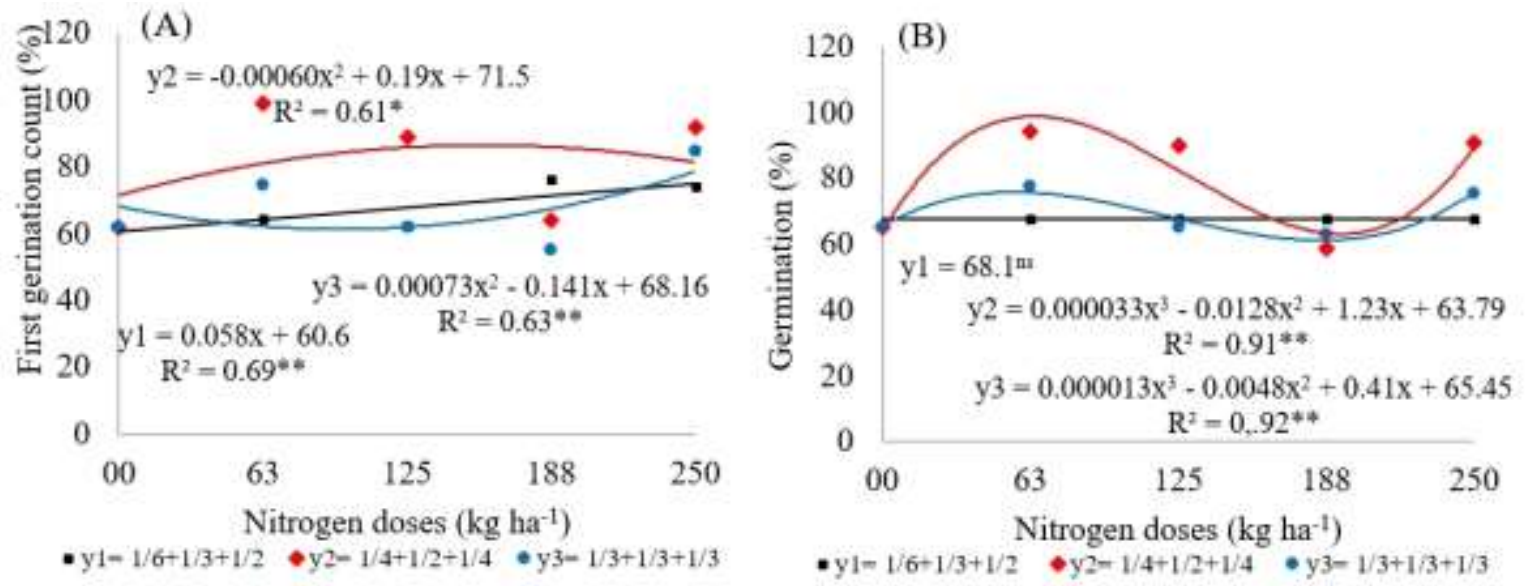

Source: Authors. 
The factor splitting and the interactions between doses of $\mathrm{N}$ and splitting were not significant for all nutrients content in the seeds. There was a significant effect of doses of $\mathrm{N}$ on the contents of $\mathrm{N}, \mathrm{P}, \mathrm{K}$ and $\mathrm{Ca}$. For $\mathrm{Mg}$ and $\mathrm{S}$ contents, there was no effect of the treatments, with means of 5.77 and $1.78 \mathrm{~g} \mathrm{~kg}^{-1} \mathrm{DM}$, respectively.

The nitrogen content in the seeds increased the higher the doses of $\mathrm{N}$, ranging from 51,6 to $59,1 \mathrm{~g} \mathrm{~kg}^{-1} \mathrm{DM}$, an increase of $15.4 \%$ in the highest dose $\left(250 \mathrm{~kg} \mathrm{ha}^{-1}\right)$ when compared to the control (dose 0) (Figure 5A). The phosphorus content was adjusted to the quadratic equation, with maximum values estimated for $\mathrm{P}$ content of $10.1 \mathrm{~g} \mathrm{~kg}^{-1} \mathrm{DM}$ at the dose $197 \mathrm{~kg}^{-1}$ of $\mathrm{N}$ (Figure 5B). For potassium and calcium contents it was also observed quadratic equation, with minimum values estimated for $\mathrm{K}$ content of $8.3 \mathrm{~g} \mathrm{~kg}^{-1} \mathrm{DM}$ at the dose of $158 \mathrm{~kg} \mathrm{ha}^{-1}$ of $\mathrm{N}$ and for Ca content of $2.9 \mathrm{~g} \mathrm{~kg}^{-1} \mathrm{DM}$ at the dose of $166 \mathrm{~kg}$ ha' N (Figures 5C and 5D).

Figure 5. Nitrogen (A), phosphorus (B), potassium (C) and calcium (D) contents of zucchini seeds as a function of the nitrogen doses. Crop 2015.
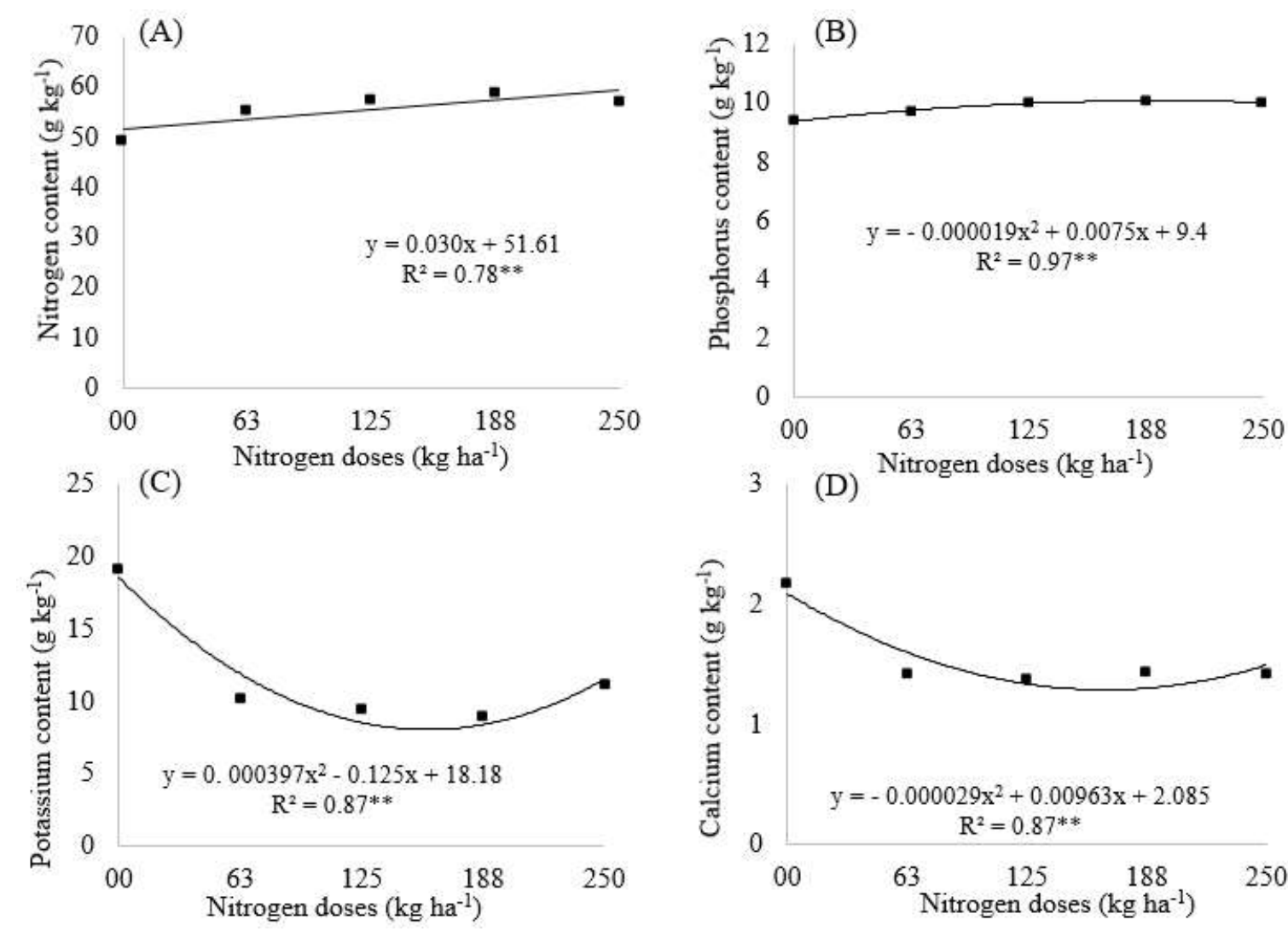

Source: Authors.

\section{Discussion}

The fact that no differences were observed for number of fruits per plant in crop 2014 could be due to the fruits being harvested ripe, that is, when it is normal to get only 1 or 2 fruits per plant, because the other fruits are aborted. But, when fruits are harvested before ripening, it is common to harvest more than ten fruits per plant, because, in this case, the fruits are weak drains, while ripe fruits are strong drains that promote abortion of young fruits in the plant (Stephenson et al. 1988; Cardoso \& Souza Neto 2016).

For the characteristics related to seed production, number of seeds per fruit is dependent of number of visits of bee pollinators (Stephenson et al. 1988) that, probably, was about the same for all flowers. 
The application of nitrogen in top dressing aims to complement the nutrition providing this nutrient during the development of the seeds, period of greatest nutrients demand, as illustrated in Figure 1.

In relation to Figure 2, the greater production of seeds in weight was due to the greater 100 seed weight, because there was not an increase in number of seeds produced per fruit and per plant. Nitrogen, together with potassium, are usually the most extracted by plants and $\mathrm{N}$ is usually the most accumulated in seeds (Cardoso 2011), because they participate in the constitution of proteins, starch synthesis, embryo formation and it is important in the initial development of the embryo during germination (Kolchinski \& Schuch 2004). The increasing in seed production was linear, until dose $250 \mathrm{~kg} \mathrm{ha}^{-1}$ of N, that is 200\% higher than the dose recommended by Trani and Raij (1997) for zucchini (immature fruit) production, showing that, probably, the need for $\mathrm{N}$ for seed production should be higher than the need for immature fruit production.

The increase of the $\mathrm{N}$ dose when applied in higher quantities in the flowering and fruiting phases allowed an increase in the viability and vigor of the seeds (Figure 3). According to Carvalho and Nakagawa (2012), nitrogen can influence the physiological quality of the seeds, but their effects vary with the environmental conditions and the stage of development of the plant in which the fertilizer application occurs.

About the first count and the total germination (Table 1), nitrogen fertilization done in the highest proportion in the $2^{\text {nd }}$ application, in the $1 / 4+1 / 2+1 / 4$ splitting, may have favored the physiological quality because it provides a higher amount of $\mathrm{N}$, compared to the other two splitting, just in the phase of the cycle that demands the greatest quantity of this nutrient which is the beginning of the development of fruits and seeds. Nitrogen is the nutrient that has the greatest influence on the vigor of the seeds and when applied in the beginning of flowering, the same is directed to the seeds (Cardoso 2011; Carvalho \& Nakagawa 2012).

The germination values obtained (Figure 4) were smaller than those of the first count because of the evaluation method adopted, that is, for the first count, the radicle protrusion of at least $4 \mathrm{~mm}$ in length was considered and for final germination only normal seedlings, according to Brasil (2009).

As the results of this research (Figure 5A), Toledo et al. (2009) also observed a linear increase in N content in bean seeds with increasing $\mathrm{N}$ dose applied at the flowering and grain filling stage. This increase in content of $\mathrm{N}$ is due the greater availability of $\mathrm{N}$ in soil to the plants and because $\mathrm{N}$ is easily redistributed from the leaves to the fruits and seeds.

In comparison to determination of the macronutrients content in seeds (Figures 5A-D), Patel (2013), in pumpkin, obtained average contents of 48.37; 12.33; 8.09; 0.46 and $5.92 \mathrm{~g} \mathrm{~kg}^{-1} \mathrm{DM}$ of $\mathrm{N}, \mathrm{P}, \mathrm{K}, \mathrm{Ca}$ and $\mathrm{Mg}$, respectively, while ElAdawy \& Taha (2014), in pumpkin seeds, related $30.7 \mathrm{~g} \mathrm{~kg}^{-1}$ of $\mathrm{N}, 10.9 \mathrm{~g} \mathrm{~kg}^{-1}$ of P, $9.8 \mathrm{~g} \mathrm{~kg}^{-1}$ of K, $1,3 \mathrm{~g} \mathrm{~kg}^{-1}$ of Ca and $4.8 \mathrm{~g}$ $\mathrm{kg}^{-1}$ of $\mathrm{Mg}$. The values are a little different probably due differences in cultivar, soils, fertilization, and climatic conditions. But the decreasing order of the macronutrients obtained in the seeds are the same: $\mathrm{N}>\mathrm{P}>\mathrm{K}>\mathrm{Mg}>\mathrm{S}>\mathrm{Ca}$. Just $\mathrm{S}$ was not evaluated by the other authors and it is not possible to confirm the order.

Probably, the greatest accumulation of $\mathrm{N}$ in the seeds is due to the fact that this nutrient participates in the constitution of the proteins, starch synthesis, formation of the embryo and reserve tissue, viability and vigor, and it is important in the initial development of the embryo during germination (Kolchinski \& Schuch 2004; Carvalho \& Nakagawa 2012). Phosphorus is important in phytin composition, the main form of energy storage in seeds (Carvalho \& Nakagawa 2012; Kano et al. 2012). These nutrients ( $\mathrm{N}$ and $\mathrm{P}$ ) are the most important in seed formation of most species, as reported by several authors (Kano et al. 2011; Cardoso 2011; Cardoso et al. 2016). On the other hand, Ca is the nutrient with lower seed content, a fact probably related to the small mobility in the plant by the phloem (Grangeiro et al. 2007; Malavolta 2006). According to Cardoso et al. (2016), the accumulation of $\mathrm{Ca}$ in the seeds should only occur by absorption and transport during the maturation of the seeds, without redistribution from the leaves in senescence to the seeds. 


\section{Conclusion}

The treatments did not result in an increase in fruit production and number of seeds produced per plant.

In crop 2014, the higher the nitrogen doses, the higher the seed production (weight) per fruit and per plant and the 100 seeds weight.

In crop 2015, the splitting $1 / 4+1 / 2+1 / 4$ showed, on average, the highest values related to the quality (germination and vigor) of zucchini seeds.

In the seeds, the decreasing order of the macronutrients content was $\mathrm{N}>\mathrm{P}>\mathrm{K}>\mathrm{Mg}>\mathrm{S}>\mathrm{Ca}$.

The higher the nitrogen dose, the higher the nitrogen and phosphorus content in the seeds.

\section{References}

Araújo, H. S., et al. (2013). Potassium top dressing levels on fruit yield of summer squash. Revista de Ciências Agrárias, 36(3), 303-309.

Araújo, H. S., et al. (2015). Macronutrients content and extraction in zucchini plants in function of potassium top dressing levels. Brazilian Journal of Agricultural Sciences, 10(3), 389-395.

Brasil. Ministério da Agricultura, Pecuária e Abastecimento. (2009). Regras para análise de sementes (Seed analysis rules). Mapa/ACS.

Cardoso, A. I. I. (2011). Nutrição e adubação em campos de produção de sementes de hortaliças (Nutrition and fertilization in vegetable seed production). In: Nascimento, W. M. (Ed.). Hortaliças: tecnologia de produção de sementes. BrasíliEmbrapa Hortaliças, pp. 109-134.

Cardoso, A. I. I. \& Souza Neto, I. L. (2016). Melhoramento de abóbora, abobrinha e moranga (Squash and zucchini breeding). In: Nick, C.; Borém, A. (Eds.). Melhoramento de hortaliças. Editora UFV, pp. 61-94.

Cardoso, A. I. I., et al. (2016). Phosphate fertilization over the accumulation of macronutrients in cauliflower seed production. Horticultura Brasileira, 34(2), 196-201.

Carvalho, N. M. \& Nakagawa, J. (2012). Sementes: ciências, tecnologia e produção. Ed, Funep.

Corrêa, C. V.; Gouveia, A. M. S. \& Cardoso, A. I. I. (2014). Nutrients content in function of plants number per hole and nitrogen rates in top dressing in squash yield. Revista Cultivando o Saber, 7(4), 343-352.

Cunha, A. R. \& Martins, D. (2009). Classificação climática para os municípios de Botucatu e São Manuel, SP. Irriga, 14(1), 1-11.

El-Adawy, T. A. \& Taha, K. M. (2014). Characteristics and composition of watermelon, pumpkin, and paprika seed oils and flours. Journal of Agricultural and Food Chemistry, 49, 253-1259.

Ferreira, D. F. (2011). Sisvar: a computer statistic analysis system. Ciência e Agrotecnologia, 35(6), 1039-1042.

Grangeiro, L. C. et al. (2007). Accumulation and exportation of nutrients in beet crop. Ciência e Agrotecnologia, 31(2), 267-273.

Kano, C.; Cardoso, A. I. I. and Villas Bôas, R. L. (2011). Nutrients uptake by lettuce plants for seed production. Horticultura Brasileira, $29(1), 70-77$.

Kano, C.; Cardoso, A. I. I. \& Villas Bôas, R. L. (2012). Phosphorus rates on yield and quality of lettuce seeds. Horticultura Brasileira, 30(4), 695-698.

Kolchinski, E. M. \& Schuch, L. O. B. (2004). Relationships between nitrogen fertility and grain and seeds quality in oats. Ciência Rural, 34(2), 379-383.

Magro, F. O., et al. (2010). Organic compost in broccoli seed yield and quality. Ciência e Agrotecnologia, 34(3), 596-602.

Malavolta, E. (2006). Manual de nutrição mineral de plantas. Agronômica Ceres.

Malavolta, E.; Vitti, G. C. \& Oliveira, S. A. (1997). Avaliação do estado nutricional das plantas: Princípios e aplicações. (2a ed.), Potafós.

Patel, S. (2013). Pumpkin (Cucurbita sp.) seeds as nutraceutic: a review on status quo and scopes. Mediterranean Journal of Nutrition and Metabolism, 6, 183189.

Pedrosa, M. W., et al. (2012). Yield and quality of hybrid squash (pumpkin) in response to nitrogen doses. Horticultura Brasileira, 30(2), 355-358.

Queiroga, R. C. F., et al. (2007). Yield and quality of muskmelon fruits cultivated in greenhouse with doses of nitrogen. Horticultura Brasileira, 25(4), 550556.

Stephenson, A. G.; Devlin, B. \& Horton, J. B. (1988). The effects of seed number and prior fruit dominance on the pattern of fruit production in Cucurbita pepo (zucchini squash). Annals of Botany, 62, 653-661.

Trani, P. E. \& Raij, B. (1997). Hortaliças. In: Raij, B. et al., eds. Recomendações de adubação e calagem para o Estado de São Paulo. (2a ed.), IAC, pp. 157164. 